\title{
Pengaruh Konsentrasi Ekstrak Tumbuhan Bandotan (Ageratum conyzoides L.) dan Waktu Pemberian Terhadap Pertumbuhan dan Hasil Tanaman Sawi (Brassica juncea L.)
}

\author{
Effect of Concentration of 'Bandotan' (Ageratum conyzoides L.) Extract and Application Time on \\ the Growth and Yield of Green Mustard (Brassica juncea L.)
}

\section{Avia J. Matatula, Maria S. Batlyel, Abdul K. Kilkoda*}
Program Studi Agroteknologi, Jurusan Budidaya Pertanian, Fakultas Pertanian, Universitas Pattimura, Jl. Ir. M. Putuhena, Kampus Poka, Ambon 97233, Indonesia
*E-mail Penulis Korespondensi: boimkilkoda@gmail.com

\begin{abstract}
The presence of weeds in crop cultivation has a negative effect on the crop because of their high competitiveness. One of the roles of weeds as allelopathy because weeds release chemical compounds that can inhibit growth and kill plants around them. This study aimed to determine the effect of concentration of 'bandotan' plant extracts plants at various application times on the growth and yield of mustard. The research was carried out at the Greenhouse of the Faculty of Agriculture, Pattimura University, from November 2017 to January 2018. This study used an experimental method with a completely randomized design (CRD) involving two factors and with three replications. The first factor was 'bandotan' extract with 4 concentration levels: control (no extract), $100 \mathrm{~g} / \mathrm{L}, 200 \mathrm{~g} / \mathrm{L}$ and $300 \mathrm{~g} / \mathrm{L}$. The second factor was application time with three levels: 5 days after planting (DAP), 10 DAP, and 15 DAP. The variables observed included plant height, leaf number, leaf area, fresh crop weight, and crop dry weight. Data analysis of each variable was conducted using the analysis of variance. If there was a significant treatment effect, it proceeded with the Tukey test at the level of $\alpha=0.05$. The results showed that the concentration of 'bandotan' extract did not significantly affect all observation variables (plant height, leaf number, leaf area, fresh crop weight, and dry weight of mustard). Time of 'bandotan' extract application did not significantly affect all observation variables (plant height, leaf number, leaf area, fresh crop weight, and dry weight of mustard). The interaction between 'bandotan' extract concentration and application time did not significantly affect all observed variables.
\end{abstract}

Keywords: application time, 'bandotan' extract, green mustard, growth and yield

\begin{abstract}
ABSTRAK
Keberadaaan gulma pada tanaman budidaya berpengaruh negatif pada tanaman itu karena daya kompetitif yang tinggi. Salah satu peran gulma sebagai alelopati karena gulma mengeluarkanbahan senyawa kimia yang dapat menghambat pertumbuhan dan mematikan tumbuhan yang ada disekitarnya. Penelitian ini bertujuan untuk menemukan pengaruh konsentrasi ekstrak tumbuhan gulma 'bandotan' pada berbagai interval waktu terhadap pertumbuhan dan hasil tanaman sawi. Penelitian ini dilaksanakan di Rumah Kaca Jurusan Budidaya Pertanian, Fakultas Pertanian, Universitas Pattimura, dan berlangsung pada November 2017 sampai Januari 2018. Penelitian ini menggunakan metode eksperimental dengan pola Rancangan Acak Lengkap, dengan dua faktor yang diteliti dan dengan tiga ulangan. Faktor pertama adalah ekstrak bandotan dengan 4 taraf konsentrasi: kontrol, 100 g/L, 200 g/L dan 300 g/L. Faktor kedua adalah waktu dengan tiga taraf: 5 HST, 10 HST dan 15 HST. Parameter yang diamati adalah tinggi tanaman, jumlah daun, luas daun tanaman, berat segar tanaman dan berat kering tanaman. Analisis data dari peubah yang diamati, dilakukan dengan menggunakan Analisis Ragam dan apabila terdapat pengaruh perlakuan nyata maka di lanjutkan denganuji BNJ pada taraf $\alpha=0,05$. Hasil penelitian menunjukkan bahwa pengaruh ekstrak tumbuhan bandotan tidak berpengaruh nyata terhadap semua variable pengamatan (tinggi tanaman, jumlah daun, luas daun, berat segar dan berat kering tanaman sawi). Perlakuan interval waktu pemberian ekstrak tumbuhan bandotan tidak berpengaruh nyata terhadap semua variabel pengamatan. Interaksi antara ekstrak tumbuhan bandotan juga tidak berpengaruh nyata terhadap semua variabel pengamatan.
\end{abstract}

Kata kunci: ekstak bandotan, interval waktu, pertumbuhan dan hasil, tanaman sawi 


\section{PENDAHULUAN}

Sayuran adalah salah satu komponen dari menu makanan yang sehat, maka tidak heran jika kebutuhan sayuran dewasa ini semakin meningkat sejalan dengan kesadaran masyarakat tentang kesehatan. diantara bermacam-macam jenis sayuran yang dapat dibudidayakan, tanaman sawi (Brassica juncea L.) merupakan salah satu komoditas yang mempunyai nilai komersial tinggi (Rukmana, 1994). Tanaman sawi merupakan sayuran daun yang termasuk dalam family Brassicaceae yang memiliki nilai ekonomis tinggi karena kaya akan serat, dankandungan gizinya tinggi. Sawi mengandung vitamin $\mathrm{A}$, vitamin $\mathrm{B}$, vitamin $\mathrm{C}$, kalium, kalsium, magnesium, zat besi, fosfor folat, protein, lemak, baik yang berguna bagi kesehatan tubuh manusia. Selain memiliki kandungan vitamin dan gizi yang penting bagi tubuh, tanaman sawi diketahui dapat menghilangkan rasa gatal di tenggorokan pada penderita batuk. Sawi yang dikonsumsi berfungsi pula sebagai penyembuh sakit kepala. Sebagian masyarakat pun mempercayai tanaman ini bekerja sebagai bahan pembersih darah.

Sawi merupakan salah satu jenis sayur yang digemari oleh masyarakat mulaikelas bawah hingga golongan kelas atas (Rukmana, 1994). Salah satu faktor penghambat hasil tanaman sawi adalah gulma yang tumbuh bersamaannya. Gulma merupakan organisme penganggu tanaman (OPT) yang mampu menurunkan pertumbuhan dan perkembangan serta produktivitas tanaman. Keberadaaan gulma pada tanaman budidaya berpengaruh negatif pada tanaman karena daya kompetitif yang tinggi sehingga terjadi persaingan. Salah satu peran gulma sebagai alelopati karena gulma mengeluarkanbahan senyawa kimia yang dapat menghambat pertumbuhan dan mematikan tumbuhan lain yang ada disekitarnya (Sastroutomo, 1990; Enhelling, 1995).

Istilah alelopati pertama kali digunakan oleh Molich pada tahun 1937 yang diartikan sebagai interaksi biokimiawi secara timbal balik yang bersifat penghambatan maupun perangsangan antara semua jenis tumbuhantermasuk semua mikroorganisme. Rice (1984) mendefenisikan alelopati sebagai pengaruh yang merugikan dari suatu tanaman terhadap tanaman lain baik langsung maupun tidak langsung melalui senyawa kimia racun yang di keluarkan kelingkungan tumbunya. Singh dan Heldman (2001) mengemukakan bahwa alelopati menunjukan efek langsung atau tidak langsung tanaman ke tanaman lain melalui pelepasan zat kimia kelingkungannya dan memegang peran penting dalam agroekosistem. Senyawa-seyawa alelopati dapat ditemukan pada jaringan tumbuhan (daun, batang, akar, bunga, buah, dan biji). Senyawa-senyawa tersebut dapat terlepas dari jaringan tumbuhan melalui berbagai cara, yaitu melalui penguapan, eksudat akar, pencucian dan pembusukan bagian-bagian organ yang mati.

Salah satu gulma yang dapat menekan pertumbuhan sawi adalah bandotan (Ageratum conyzoides L.) yang merupakan gulma berdaun lebar yang sering kali populasinya lebih dominan dibandingkan dengan gulma lainnya dalam suatu lahan. A. conyzoides L. diduga kuat mempunyai efek alelopati, keadaan dimana suatu gulma atau bahan tanaman mengeluarkan eksudat kimia yang dapat menekan pertumbuhan tanaman/tumbuhan (Sukman dan Yakup, 1999). A. conyzoides L. merupakan gulma semusim, dengan nama lokal bandotan, di Jawa barat dinamakan wedustan, sedangkan di Maluku dinamakan tanaman bau kambing karena tanaman ini mengeluarkan aroma mirip dengan bau kambing. A. conizoides L. mempunyai daya adaptasi yang tinggi sehingga mudah tumbuh di mana-mana dan sering menjadi gulma yang sangat merugikan para petani (Sukamto, 2007). Menurut Ming (1999) penyebaran A. conyzoides L. cukup luas mencapai daerah tropis dan sub tropis.

A. conyzoides $\mathrm{L}$. dapat di gunakan sebangai obat, pestisida dan herbisida. A. conyzoides $L$ telah di gunakan secara luas dalam penggobatan secara tradisional oleh masyarakat di berbagai belahan dunia (Ming, 1999; Sukamto, 2007). Di India di gunakan sebagai bakterisida dan di Brasil di gunakan untuk menangani kolik dan diare, rhematik dan efektik mengobati luka bakar Di Indonesia digunakan sebangai tanaman obat. Bagian akar dari tumbuhan ini di gunakan untuk menurunkan demam sedangkan bagian daunnya di gunakan sebagai pencuci mata serta mengobati sakit perut dan luka (Sukamto, 2007). Di lain pihak, A. conyzoides L. merupakan salah satu gulma yang dapat menekan pertumbuhan sawi. A. conyzoides L. sering kali populasinya lebih dominan dibandingkan gulma lainnya dalam suatu lahan. A. conyzoides L. diduga kuat mempunyai alelopati (Sukman dan Yakup, 1991).

Hasil penelitian yang dilakukan Hafsah et al. (2012), menyatakan bahwa efek alelopati A. conyzoides L. terhadap pertumbuhan sawi dengan interval waktu pemberian tidak berpengaruh nyata, namun terdapat konsentrasi terbaik dari perlakuan yang dicoba yaitu $300 \mathrm{~g} / \mathrm{L}$ dengan interval waktu pemberian terbaik yaitu 10 hari setelah tanam (HST).

\section{BAHAN DAN METODE}

\section{Tempat dan Waktu Penelitian}

Penelitian ini di laksanakan di rumahkaca Fakultas Pertanian, Universitas Pattimura, penelitian ini berlangsung pada November 2017 sampai Januari 2018.

\section{Alat dan Bahan}

Alat yang digunakan dalam penelitian ini meliputi 36 buah polybag berukuran $30 \times 30$, gembor, ember, gelas plastik, timbangan analitik, meteran/penggaris, $\mathrm{pH}$, amplop, pisau, kalkulator, kantong plastik, parang, oven, label, alat tulis, dan kamera.

Bahan yang digunakan dalam penelitian ini adalah tanah jenis Regosol, benih sawi, pupuk kandang ayam, tumbuhan bandotan (A. conyzoides L.) dan air. 


\section{Metode Penelitian}

Penelitian ini menggunakan metode eksperimen dengan pola Rancangan Acak Lengkap (RAL) dengan dua faktor yang diteliti. Faktor pertama adalah ekstrak gulma dengan empat taraf konsentrasi, yaitu: $\mathrm{K} 0$ (kontrol), K1(100 g/L), K2 (200 g/L) dan K3 (300 g/L). Faktor ke dua adalah waktu pemberian dengan tiga taraf, yaitu: W1 (5 HST), W2 (10 HST) dan W3 (15 HST). Jumlah kombinasi perlakuan adalah $3 \times 4=12$ kombinasi. Masing masing kombinasi perlakuan di ulang sebanyaktiga kali sehinggga semua terdapat 36 satuan percobaan.

\section{Pelaksanaan Penelitian}

Pembuatan ekstrak bandotan dilakukan dengan cara mencuci semua bagian tumbuhan bandotan (daun, batang, akar) yang selanjutnya dikeringkan selama 5 menit dan ditimbang sesuai perlakuan $(100 \mathrm{~g}, 200 \mathrm{~g}$, $300 \mathrm{~g}$ ). Selanjutnya bagian-bagian tumbuhan tersebut ditumbuk sampai halus, dan ditimbang sesuai perlakuan, yakni $\mathrm{K} 1=100 \mathrm{~g}, \mathrm{~K} 2=200 \mathrm{~g}, \mathrm{~K} 3=300$, kemudian direndamkan dalam wadah yang berisi air dan dibiarkan selama 24 jam. Setelah itu ekstrak disaring dengan menggunakan kain kasa sebagai kain saring ke dalam labu Erlemeyer dan ekstrak siap digunakan.

Media persemaian tanaman sawi yang digunakan terdiri atas tanah jenis Regosol dan pupuk kandang ayam dengan perbandingan 1:1. Sebelum persemaian dilakukan perlakuan benih dengan cara benih direndam di dalam air selama 2 jam. Tujuannya adalah untuk merangsang benih dan mempercepat pertumbuhan serta perkembangan yang seragam saat benih disemaikan. Wadah persemain terdiri dari gelas aqua yang terisi media tanah, lalu disiram hingga basah atau lembab. Selanjutnya benih sawi ditabur dan setiap wadah diisi 23 benih lalu benih tersebut ditutup dengan tanah tipistipis secara merata.

Persiapan media tanam dilakukan satu minggu sebelum bibit dipindah-tanamkan. Tanah yang akan dijadikan media tanam terlebih dahulu diayak agar memisahkan tanah dari gulma, batu-batu kecil maupun kotoran lainnya. Tanah tersebut dicampur dengan pupuk kandang hingga merata dengan perbandingan 4:1. Kemudian media tanah tersebut di masukan dalam polybag ukuran diameter $30 \times 30 \mathrm{~cm}$ dengan bobot 4 $\mathrm{kg} /$ polybag.

Bibit sawi ditanam adalah yang telah berumur 3 minggu dengan jumlah daun 3-5 helai siap untuk dipindahtanamkan ke polybag atau media tanam yang telah di siapkan. Dalam proses pemindahan di lakukan secara hati-hati agar bibit tidak rusak baik batang maupun perakaran tanaman. Setelah itu disiram hingga medianya cukup basah. waktu penanaman dilakukan pada sore hari. Bibit yang sudah di tanam di polybag di atur dengan jarak $30 \times 30 \mathrm{~cm}$ antara polybag dengan polybag lainnya.

Pemberian ekstrak bandotan adalah sesuai tingkat konsentrasi kontrol (tanpa ekstrak), 100 g/L, 200 $\mathrm{g} / \mathrm{L}$ dan $300 \mathrm{~g} / \mathrm{L}$, dan diberikan sesuai perlakuan waktu pemberian yang dicobakan pada penelitian ini. Waktu pemberian ekstrak yang dicobakan adalah 5, 10, dan 15 HST dan dilakukan saat tanaman berumur sesuai dengan perlakuan waktu pemeberian.

Pemeliharaan tanaman dilakukan setelah tanam, meliputi: penyiraman dengan air, dilakukan setiap hari yaitu pada pagi haridansore hari; penyisipan/penyulaman, dilakukan untuk mengganti bibit yang mati 3-7 hari setelah tanam. Penyiangan dilakukan dengan cara mencabut gulma secara hati-hati agar tidak merusak tanaman, sekaligus dilakukan pengemburan guna menghindari pemadatan tanah.

Pemanenan dilakukan saat sawi berumur 28 HST. Cara panen sawi adalah dengan mencabut secara hati-hati agar tidak rusak atau putus. Penentuan saatnya panen sawi adalah ketika daun paling bawah menunjukkan warna kuningdan tetapi belum berbunga.

\section{Pengamatan}

Tinggi tanaman diukur dengan menggunakan meteran atau penggaris; diukur mulai dari pangkal batang sampai ujung daun tertinggi. Pengukuran pertama dilakuan pada saat tanaman berumur 14 HST dan selanjutnya pengukuran tinggi tanaman dilakukan pada saat tanaman berumur 21 dan 28 HST. Penghitungan jumlah daun dihitung pada semua daun yang telah terbuka sempurna. Jumlah daun dihitung bersamaan dengan pengukuran tinggi tanaman yaitu pada 14, 21 dan 28 HST). Pengukuran luas daun dilaksanakan di Balai besar Perbenian dan Proteksi Tanaman Perkebunan Ambon di Passo, Ambon. Penelitian tersebut dilakukan pada saat setelah dipanen; dilakukan terhadap 3 helai daun yang diambil sebagai sampel (kecil, sedang, besar) luas daun diukur menggunakan alat leaf area meter.

Berat basah diperoleh setelah panen, ditimbang dengan menggunakan timbangan analitik dan ditimbang secara terpisah bagian atastanaman (batang dan daun) dan bagian bawah tanaman (akar). Berat kering ditentukan setelah panen. Bahan dimasukkan ke dalam amplop dan diberi labels esuai perlakuan, lalu dikeringkan dioven pada suhu $80{ }^{\circ} \mathrm{C}$ selama 48 jam secara terpisah bagian atas (batang dan daun) dan bawah (akar). Setelah sampel dikeluarkan dari lemari pengering dan didiamkan selama 30 menit sebelum ditimbang.

Analisis data dari peubah yang diamati, dilakukan dengan menggunakan analisis ragam (analysis of variance) dan apabila terdapat pengaruh perlakuan yang nyata maka di lanjutkan dengan uji BNJ pada taraf $\alpha=0,05$, untuk mengetahui perbedaan masing-masing taraf perlakuan.

\section{HASIL DAN PEMBAHASAN}

Berdasarkan hasil analisis ragam, didapatkan bahwa konsentrasi ekstrak tumbuhan bandotan dan waktu pemberian tidak berpengaruh nyata terhadap 
semua variabel pengamatan. Interaksi antara konsentrasi ekstrak tumbuhan bandotan dan waktu pemberian juga tidak berpengaruh nyata terhadap semua variabel pengamatan. Dengan demikian ilustrasi tentang hasil pengamatan terhadap variable-variabel pertumbuhan dan hasil panen sawi pada minggu-minggu yang berbeda sebagai akibat dari perlakuan konsentrasi ekstrak tumbuhan bandotan dan waktu pemberiannya diberikan dalam bentuk grafik-grafik.

\section{Tinggi Tanaman}

Pada umur tanaman14 HST, tinggi tanaman tertinggi diberikan oleh konsentrasi (300 g/L) dengan nilai $18,41 \mathrm{~cm}$. Pada umur tanaman $21 \mathrm{HST}$, tinggi tanaman tertinggi juga diberikan oleh konsentrasi (300 $\mathrm{g} / \mathrm{L}$ ), yaitu dengan nilai $25,39 \mathrm{~cm}$. Sedangkan pada umur 28 HST, kontrol tanpa ekstrak bandotan memberikan nilai tertinggi pada tinggi tanaman dengan nilai $30,42 \mathrm{~cm}$. Hubungan antara tinggi tanaman sawi dengan berbagai konsentrasi ekstrak tumbuhan bandotan dapat dilihat pada Gambar 1.

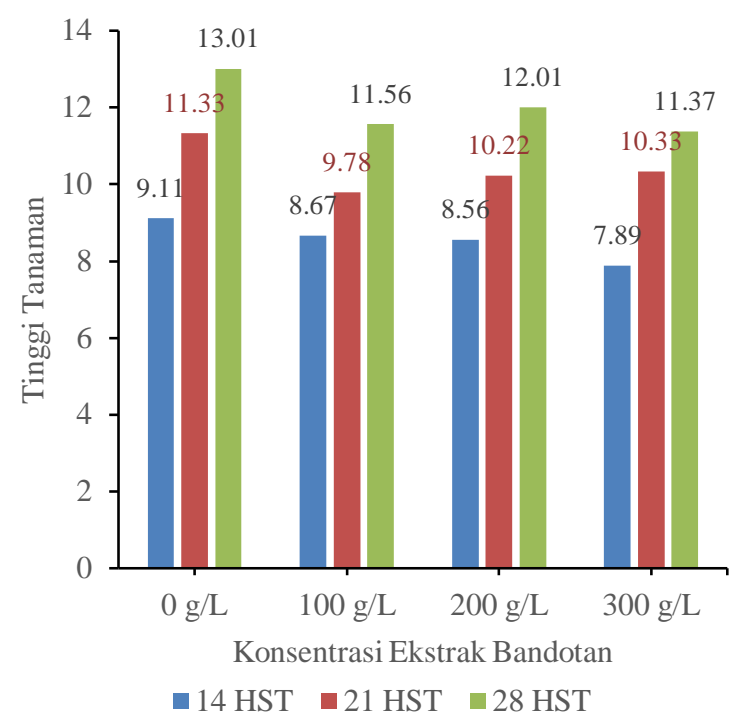

Gambar 1. Pengaruh konsentrasi ekstrak tumbuhan bandotan terhadap tinggi tanaman pada 14 21 dan 28 HST

Pada umur tanaman14 HST, tinggi tanaman tertinggi diberikan oleh waktu pemberian (10 HST) dengan nilai $18,34 \mathrm{~cm}$. Pada umur tanam $21 \mathrm{HST}$, tinggi tanaman tertinggi diberikan oleh perlakuan waktu pemberian (15 HST) dengan nilai 25,13 cm. Pada umur 28 HST, tinggi tanaman tertinggi diberikan oleh perlakuan waktu pemberian 15 HST (W3) dengan nilai $29,21 \mathrm{~cm}$. Hubungan antara tinggi tanaman sawi dengan berbagai waktu aplikasi ekstrak tumbuhan bandotan dapat dilihat pada Gambar 2.

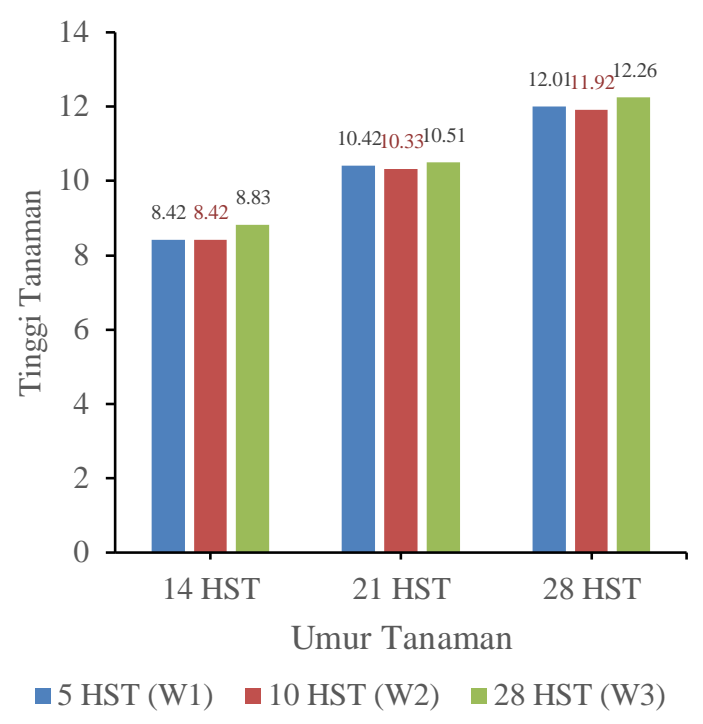

Gambar 2. Pengaruh waktu pemberian ekstrak tumbuhan bandotan terhadap tinggi tanaman pada 14, 21 dan 28 HST

\section{Jumlah Daun}

Pada setiap umur tanaman, konsentrasi ekstrak tumbuhan bandotan (kontrol) memberikan nilai jumlah daun terbanyak. Jumlah daun sawi akibat berbagai konsentrasi pemberian ekstrak tumbuhan bandotan pada berbagai umur tanamanb dapat dilihat pada Gambar 3.

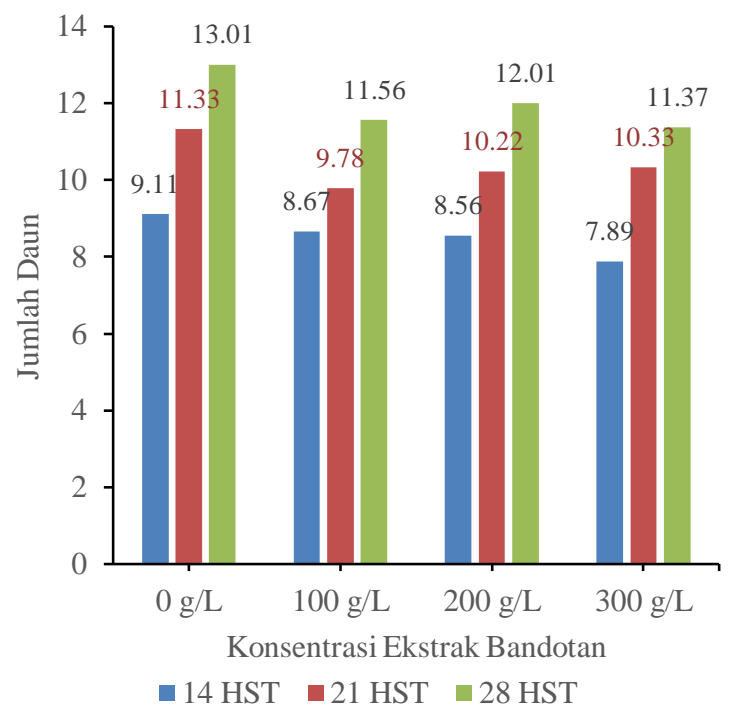

Gambar 3. Pengaruh konsentrasi pemberian ekstrak tumbuhan bandotan terhadap jumlah daun pada 14, 21 dan $28 \mathrm{HST}$

Jika dilihat pada setiap umur tanam pada Gambar 4, waktu pemberian ekstrak tumbuhan bandotan memberikan jumlah daun yang berbeda-beda. Pada umur tanaman 14 HST, jumlah daun terbanyak diberikan oleh waktu pemberian (15 HST) dengan nilai 8,83 helai. Pada umur tanam 21 HST, jumlah daun terbanyak juga 
diberikan oleh perlakuan waktu pemberian (15 HST) dengan nilai 10,51. Pada umur 28 HST, jumlah daun terbanyak juga diberikan oleh perlakuan waktu pemberian 15 HST (W3) dengan 12,26 helai.

Hubungan antara jumlah daun sawi dengan berbagai waktu aplikasi ekstrak tumbuhan bandotan dapat dilihat pada Gambar 4.

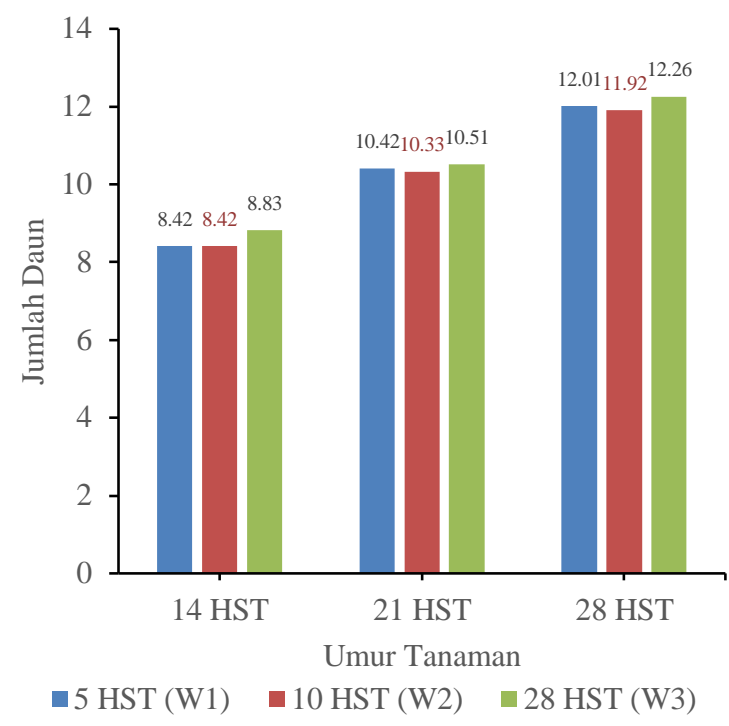

Gambar 4. Pengaruh waktu pemberian ekstrak tumbuhan bandotan terhadap jumlah daun pada 14,21 dan 28 HST

\section{Luas Daun}

Hubungan antara konsentrasi ekstrak tumbuhan bandotan dan waktu pemberiannya dengan luas daun tanaman sawi dengan dapat dilihat pada Gambar 5 dan Gambar 6.

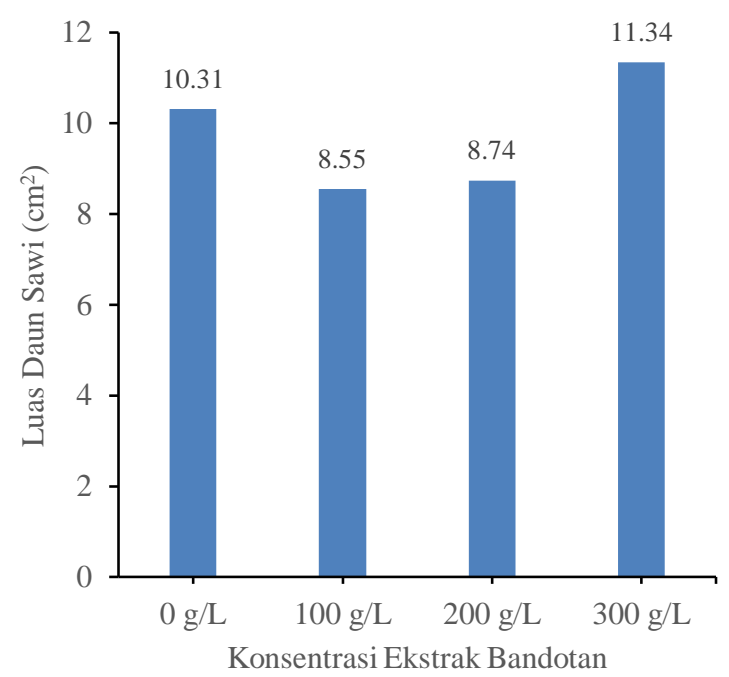

Gambar 5. Pengaruh konsentrasi ekstrak tumbuhan bandotan terhadap luas daun sawi $\left(\mathrm{cm}^{2}\right)$

Luas daun sawi terbesar diberikan oleh perlakuan konsentrasi ekstrak tumbuhan bandotan $0 \quad \mathrm{~g} / \mathrm{L}$ (K0/kontrol) dengan nilai 146,02 $\mathrm{cm}^{2}$ (Gambar 5).
Setelah itu diikuti oleh perlakuan konsentrasi (300 g/L), $(200 \mathrm{~g} / \mathrm{L})$ dan konsentrasi (100 g/L) yang mempunyai nilai yang berbeda-beda. Sedangkan pada perlakuan waktu pemberian (Gambar 6) ditunjukkan bahwa waktu pemberian 10 HST memberikan luas daun terbesar, yaitu dengan nilai $149,30 \mathrm{~cm}^{2}$ dikuti oleh 5 HST dan 15 HST.

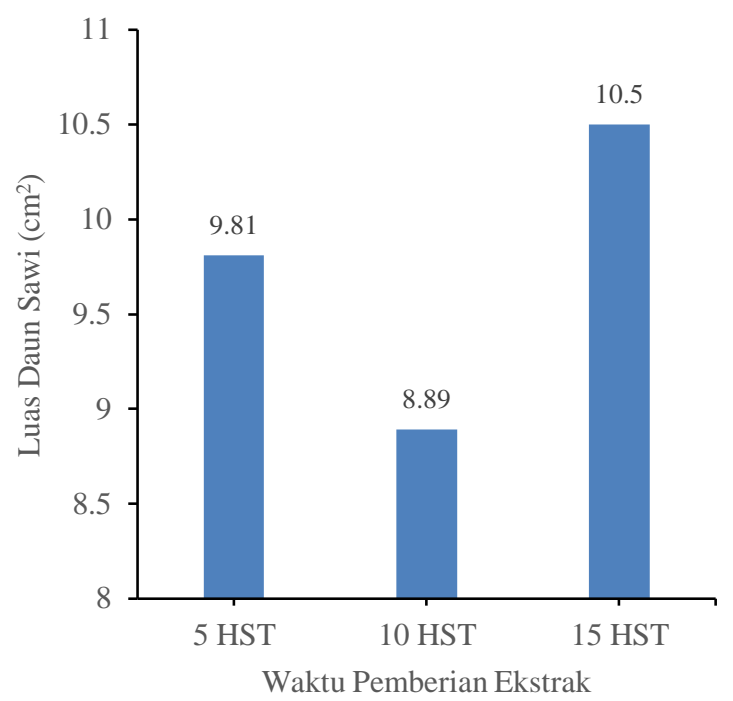

Gambar 6. Pengaruh waktu pemberian ekstrak tumbuhan bandotan terhadap luas daun $\left(\mathrm{cm}^{2}\right)$

\section{Berat Segar Tanaman}

Hubungan antara konsentrasi ekstrak tumbuhan bandotan dengan berat segar tanaman disajikan pada Gambar 7.

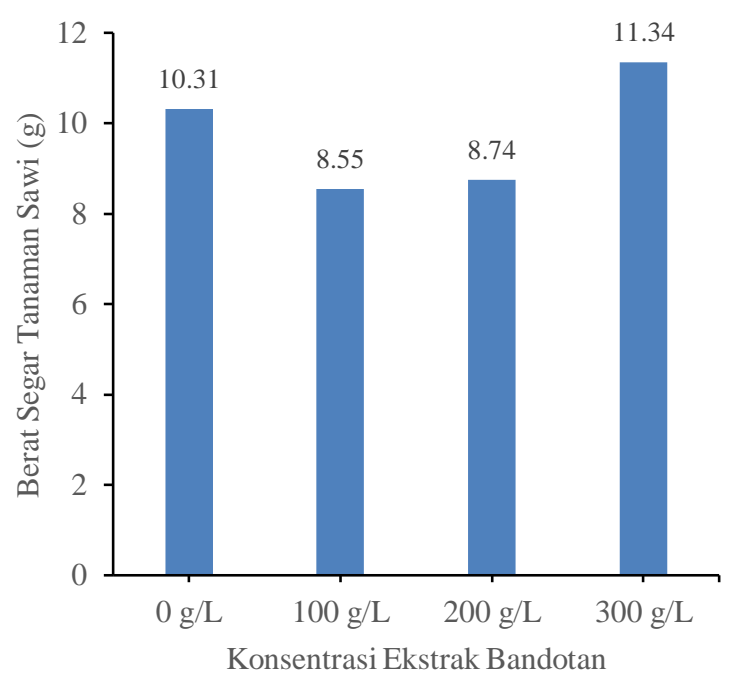

Gambar 7. Pengaruh konsentrasi ekstrak tumbuhan bandotan terhadap berat segar tanaman sawi (g)

Berat segar tanaman tertinggi diberikan oleh konsentrasi $0 \mathrm{~g} / \mathrm{L}$ (kontrol) dengan nilai 160,21 g dan 
diikuti oleh perlakuan konsentrasi $300 \mathrm{~g} / \mathrm{L}, 100 \mathrm{~g} / \mathrm{L}$ dan $200 \mathrm{~g} / \mathrm{L}$ sebagaimana ditunjukkan pada Gambar 7.

Pada perlakuan waktu pemberian (Gambar 8) ditunjukkan bahwa perlakuan waktu pemberian 5 HST (W1) memberikan berat segar tanaman sebesar 137,44 g dikuti oleh perlakuan waktu 15 SHT dan 10 HST.

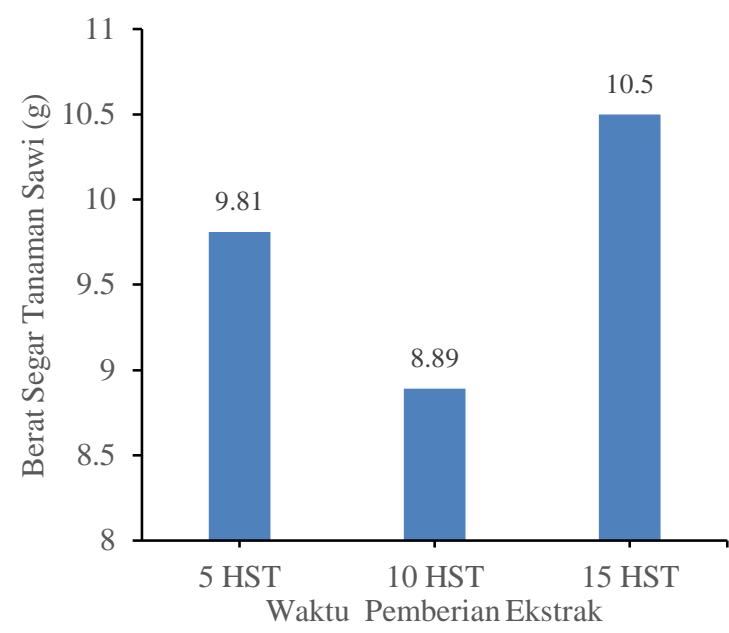

Gambar 8. Pengaruh waktu pemberian ekstrak tumbuhan bandotan terhadap berat segar tanaman $(\mathrm{g})$

\section{Berat Kering Tanaman}

Hubungan antara perlakuan konsentrasi ekstrak tumbuhan bandotan dengan berat kering tanaman dapat dilihat pada Gambar 9.

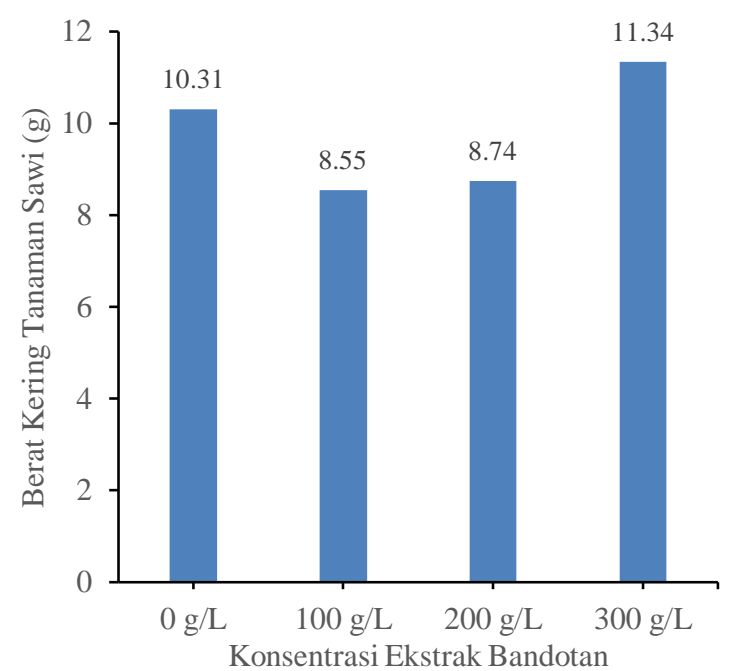

Gambar 9. Pengaruh konsentrasi ekstrak tumbuhan bandotan terhadap berat kering tanaman sawi (g)

Berat kering tanaman tertinggi diperoleh pada konsentrasi $300 \mathrm{~g} / \mathrm{L}$ dengan nilai $11,34 \mathrm{~g}$ dan diikuti oleh konsentrasi $200 \mathrm{~g} / \mathrm{L}$ dan $100 \mathrm{~g} / \mathrm{L}$ yang tidak saling berbeda nyata.
Sedangkan untuk perlakuan waktu pemberian (Gambar 10) ditunjukkan bahwa waktu pemberian 15 HST memberikan berat kering tanaman sebesar 10,50 g dikuti dengan waktu 5 HST dan 10 HST yang juga tidak saling berbeda nyata.

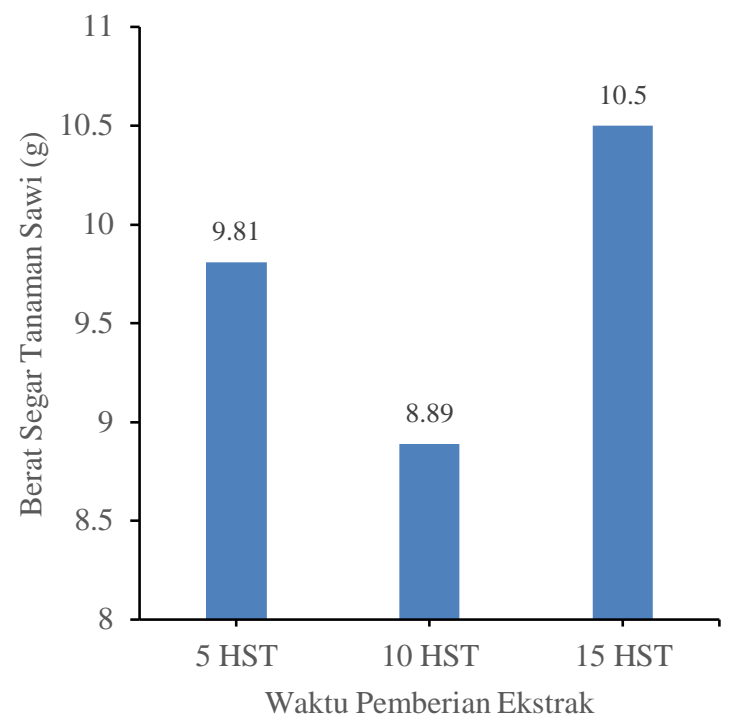

Gambar 10. Pengaruh perlakuan waktu pemberian ekstrak tumbuhan bandotan terhadap berat kering tanaman sawi (g)

\section{Pengaruh Ekstrak Tumbuhan Bandotan}

Ekstrak tumbuhan bandotan tidak berpengaruh nyata terhadap semua variable pengamatan (tinggi tanaman, jumlah daun, luas daun, berat segar dan berat kering tanaman sawi). Bahkan pada variabel tinggi tanaman umur 28 HST (Gambar 1), jumlah daun (umur 14, 21 dan 28 HST) Gambar 3, dan luas daun (Gambar 5), konsentrasi tanpa ekstrak tumbuhan bandotan (control) memberikan nilai tertinggi. Hal ini diduga bahwa ekstrak tumbuhan bandotan yang diberikan menekan dan menghambat pertumbuhan dan perkembangan tanaman sawi. Menurut Einhelling 1995 menyatakan bahwa proses tersebut di awali di membran plasma dengan terjadinya perubahan struktur modifikasi saluran membran, atau hilangnya fungsi enzim ATPase.hal ini akan berpengaruh terhadap penyerapan dan konsentrasi ion dan air yang kemudian mempengaruhi pembukaan stomata dan proses fotosintesis. Hambatan berikutnya di duga terjadi pada saat proses sintesis protein, pigmen dan senyawa karbon lain, serta aktifitas beberapa fitohormon. Sebagian atau seluruh hambatan tersebut kemudian bermuara pada terjadinya pembelahan dan pembelahan sel yang akhirnya menghambat pertumbuhan dan perkembangan tumbuhan sasaran.

Selain itu, dari hasil penelitian dapat diketahui bahwa pemberian ekstrak tumbuhan bandotan dapat menekan pertumbuhan tanaman sawi karena pada ekstrak tumbuhan bandotan mengandung bahan kimia yang dikenal dengan istilah alelopati dimana suatu 
senyawa yang dikeluarkan untuk menghambat pertumbuhan tanaman, sehingga fotosintesis, respirasi akan terganggu yang akan menyebabkan terganggunya pertumbuhan tanaman.Hasil penelitian Aini (2008) menyatakan bahwa ekstrak tumbuhan bandotan mempunyai senyawa alelopati yang dapat menghambat pertumbuhan tanaman. Ditambahkan juga oleh Javaaurora (2010) menjelaskan bahwa pemberian ekstrak tumbuhan bandotandapat menghambat pertumbuhan kacang hijau.

Menurut (Ardi, 1999) bahwa adanya senyawa alelokimia berupa fenol akan menghambat aktifitas sitokinin. Hambatan ini menyebabkan pembelahan sel pada bagian meristem pucuk terganggu pertumbuhan tinggi tanaman. Hambatan pembelahan sel oleh senyawa alelokimia ekstrak tumbuhan bandotan $(A$. conyzoides L.) dapat pula melalui gangguan aktifitas hormon tumbuhan seperti sitokinin yang berperan dalam memacu pembelahan sel (Wattimena 1988), sedangkan pada berat segar tanaman dan berat kering juga perlakuan tanpa pemberian ekstrak tumbuhan bandotan (control) memberikannilai tertinggi.Hal ini terjadi karena telah jelaskan bahwa ekstrak tumbuhan bandotan menekan dan menghambat pertumbuhan tinggi tanaman dan jumlah daun dan akan berpengaruh terhadap bobot tanaman

Table 1 juga menunjukan bahwa perlakuan tanpa pemberian ekstrak tumbuhan bandotan juga memberikan nilai tertinggi pada pada variable pengamatan berat kering tanaman. Hal ini diduga bahwa pemberian ekstrak tumbuhan bandotan akan mengakibatkan rendahnya bobot kering tanaman. Hal ini sejalan dengan pendapat Togatorop (2009) bahwa pemberian ekstrak $A$. conyzoides $\mathrm{L}$ akan menyebabkan rendahnya bobot kering tanaman. Javaaurora (2010) menjelaskan bahwa senyawa saponin yang terkandung di dalamA. conyzoides $\mathrm{L}$ akan menyebabkan hilangnya fungsi ATP, dan apabila fungsi tersebut terganggu maka akan memberikan dampak pada proses sintesis protein, pembukaan stomata dan beberapa aktifitas fitohormon.

Dari hasil pantauan dan pengamatan di lapangan jugadidapatkan bahwa tanamanyang di apalikasi ekstrak tumbuhan bandotan tidak diserang hama sedangkan tanaman tanpa pemberian ekstrak tumbuhan bandotan (tanaman control) terserang hama bahkan gejala serangan pada tanaman sangat jelas terlihat. Hal ini diduga bahwa ekstrak tumbuhan bandotan dapat berperan sebagai pestisida nabati yang dapat digunakan untuk pengendalian hama yang menyerang tanaman sawi. Seyawa bioaktif dalam bandotan mengandung saponin, flavanoid, polifenol, dan minyak atsiri yang mempengaruh terhadap sistim saraf otot, keseimbangan hormon, produksi, perilaku berupa penolak, penarik, anti makan dan sistim pernafasan OPT. Hal ini sesuai dengan pendapat Astriani (2010) yang menyatakan bahwa bandotan yang di anggap sebagai gulma ternyata mempunyai manfaat sebangai pestisida, karena mengandung saponin, flavanoid, polifenol dan minyak atsiri dan bersifat toksik sehingga menyebabkan hama cenderung diam. Gangguan metabolisme mungkin juga di sebabkan karena terdapatnya senyawa tanin dalam makanan yang dapat mengganggu aktifitas enzim pencernaan hama (Astriani,2010).

\section{Pengaruh Interval Waktu}

Hasil penelitian (Tabel 1) menunjukan bahwa perlakuan interval waktu pemberian ekstrak tumbuhan bandotan tidak berpengaruh nyata terhadap semua variabel pengamatan, akan tetapi pada setiap variable pengamatan memberikan nilai yang bervariasi danberbeda.Pada tinggi tanaman (Gambar 2) umur 14 HST dan luas daun tanaman (Gambar 6), perlakuan 10 HST (W2) memberikan nilai tertinggi, hal ini diduga bahwa perlakuan W2 lebih baik dari perlakuan 5 HST (W1), namun setelah tanaman berumur 21 HST dan 28 HST, perlakuan 15 HST (W3) memberikan hasil terbaik.Hal ini diduga bahwa tanaman sawi akan serap ekstrakAgerantum conyzoides untuk pertumbuhan tinggi tanaman pada perlakuan interval waktu yang lebih besar. Pada berat kering tanaman dan jumlah daun umur tanam 14, 21 dan 28 HST, perlakuan interval waktu 15 HST (W3) rata-rata memberikan hasil terbaik.Hal ini juga diduga bahwa tanaman akan serap ekstrak Agerantum conyzoides untuk pertumbuhan jumlah daun itu pada perlakuan interval waktu yang lebih besar, sedangkan pada variabel pengamatan berat segar tanaman, perlakuan interval waktu 5 HST (W1) memberikan hasil terbaik dibandingkan dengan perlakuan interval waktu 10 HST (W2) dan 15 HST (W3).

\section{Pengaruh Ineraksi Antara Ekstrak Tumbuhan Bandotan dan Berbagai Interval Waktu}

Hasil penelitian (Tabel 1) menunjukan bahwa interaksi antara ekstrak tumbuhan bandotan tidak berpengaruh nyata terhadap semua variabel pengamatan. Hal ini diduga bahwa tidak adanya kolaborasi antara kedua perlakuan tersebut sehingga tidak memberikan pengaruh terhadap pertumbuhan dan hasil tanaman sawi.dan selain itu, diduga bahwa faktor tunggal ekstrak tumbuhan bandotan dan interval waktu aplikasi tidak memberikan pengaruh yang nyata sehingga mengakibatkan interkasi dari kedua faktor tersebut juga tidak berpengaruh nyata.

Hasil tersebut juga dipengaruhi oleh faktor lingkungan karena tanaman dalam proses pertumbuhan selain dipengaruhi oleh kandungan unsur hara, juga di pengaruhi oleh keadaan lingkungan sekitar.

Suhu udara yang di kehendaki untuk pertumbuhan tanaman sawi adalah daerah yang mempunyai suhu malam hari $15,6^{\circ} \mathrm{C}$ dan siang hari $21,1^{\circ} \mathrm{C}$. dan untuk pertumbuhan tanaman sawi yang baik membutukan suhu udara yang berkisar dari $19-21^{\circ} \mathrm{C}$ (Sastrahidayat dan Soemarno, 1996). Sedangkan suhu udara rumah kaca tempat penelitian berkisar dari 28$51^{\circ} \mathrm{C}$.

Faktor lingkungan yang turut mempengaruhi pertumbuhan dan hasil tanaman sawi adalah suhu, 
kelemban, serta tingkat serangan hama dan penyakit. suhu merupakan faktor lingkungan yang perpengaruh terhadap pertumbuhan dan perkembangan tanaman. karena suhu berpengaruh terhadap laju metabolisme, fotosintesis respirasi dan transpirasi tumbuhan. Suhu yang tinggi akan mengakibatkan laju fotorespirasi yang berarti menurunkan hasil bersih fotosintesis. Peningkatan suhu akan menyebabkan perubahan terhadap reaksi-reaksi biokimia seperti hidrolisasi air, fiksasi, reduksi $\mathrm{CO}_{2}$ peningkatan yang sangat tinggi akan menyebabkan denaturasi enzim yang pada akhirnya akan menyebabkan kerusakan pada fotosintesis tanaman (Gardner et al., 1991).

Kelemban udara menentukan kapasitas udara untuk menampung uap air sehingga laju kehilangan air dari tanaman (transpirasi) sangat bergantung olehnya, selanjutnya akan mempengaruhi potensial air daun. Jika kelembaban rendah, laju transpirasi meningkat sehingga penyerapan air dan zat-zat mineral juga meningkat. Hal itu akan meningkatkan ketersediaan nutrisi untuk pertumbuhan tanaman. Jika kelembaban tinggi, laju transpirasi rendah sehingga penyerapan zat-zat nutrisi juga rendah. Kondisi ini akan mengurangi ketersediaan nutrisi untuk pertumbuhan kelembaban udara menentukan kapasitas udara untuk menampung uap air sehingga laju kehilangan air dari tanaman (transpirasi) sangat bergantung olehnya, sehingga dapat berpengaruhi potensi air daun, Jika kelembaban rendah, laju transpirasi meningkat sehingga penyerapan air dan zat-zat mineral juga meningkat. Hal itu akan meningkatkan ketersediaan nutrisi untuk pertumbuhan tanaman.

\section{KESIMPULAN}

Dari hasil penelitian dapat disimpulkan:

1. Ekstrak tumbuhan bandotan dan interval waktu pemberian tidak berpengaruh terhadap pertumbuhan dan hasil tanaman sawi.

2. Cairan ekstrak tumbuhan bandotan yang mengandung senyawa alelopati ternyata tidak menghambat pertumbuhan dan perkembangan tanaman sawi.

\section{DAFTAR PUSTAKA}

Aini, B. 2008. Pengaruh Ekstrak Alang-alang (Imperata cylindrica), Bandotan (Ageratum conyzoides) dan Teki (Cyperus rotundus) Terhadap Perkercambahan Beberapa Varietas Kedelai (Glycine $\max \mathrm{L}$ ). Skripsi. Universitas Islam Negeri Malang, Malang.

Ardi. 1999. Potensi alelopati akar rimpang alang-alang (Imperata cylindrica) terhadap Mimosa pudica L. Stigma 7(1): 66-68.

Astriani, D. dan W. Dinarto. 2010. Uji toksisitas beberapa gulma sebagai pestisida nabati hama bubuk pada penyimpanan benih jagung. Jurnal Agrisains 1(2): 54-64.

Enhelling, F.A. 1995. Allelopathy: current status and future goals. In: K. Inderjit, M.M Dakhshini and FA. Einhelling (Eds) ACS Symposium Series: Allelopaty organism, Processes and Aplication, Vol. 582, American Chemical Society, Washington DC. DOI: 10.1021/bk-1995-0582. ch001

Gardner, F.P., R.B. Pearce dan L.R. Mitchell. 1991. Fisiologi Tanaman Budidaya. Penerjemah: H. Susilo, UI Press, Jakarta. ISBN: 979456088X.

Hafsah, S., M.A. Ulim, dan C.M. Novayanti. 2011. Efek alelopati Ageratum conyzoides terhadap pertumbuhan sawi. Jurnal Floratek $8: 18-24$

Javaaurora. 2010. Daun wedusan (Ageratum conyzoides L.) ternyata mampu menghambat pertumbuhan tinggi tanaman dan jumlah daun kacang hijau (Phaseollus radiatus). http://erickbio.wordpress.com/2010/07/01/

Ming, L.C., 1999, Ageratum conyzoides L.: A Tropical Source of Medicinal and Agricultural Product. In: J. Janick (Ed.), Perspectives on new crops and new uses, p. 469-473. ASHS Press, Alexandria, VA.

Rice, 1984, Allelopaty, 2nd Edition, Academic Press, New York.

Rukmana, R. 1994. Bertanam Patsai dan Sawi. Kanisius. Yogyakarta.

Sastrahidayat, H.I.R. dan D.S. Soemarno. 1991. Budidaya Tanaman Tropika. Usaha Nasional, Surabaya.

Sastroutomo, S.S. 1990. Ekologi Gulma. Gramedia Pustaka Utama. Jakarta. ISBN: 0410188667.

Singh, R. P. dan R. Heldman. 2001. Introduction to Food Engineering. 3rd Edition. Academic Press. Glasgow.

Sukamto. 2007. Babandotan (Ageratum conyzoides L.) tanaman multi fungsi. Warta Puslitbangbun 13, Pusat Penelitian dan Pengembangan Perkebunan, Bogor.

Sukman dan Yakub. 1999. Gulma dan Teknik Pengendaliannya. Fakultas Pertanian Universitas Sriwijaya, Palembang.

Togatorop. D. A. 2009. Studi alelopati Wedelia tribobata, Ageratum conyzoides, Chromolaena odoratdan, Mikania micrantha terhadap pertumbuhan dan hasil sawi. Prosiding Seminar Nasional dan Rapat Tahunan Dekan Bidang Ilmu-Ilmu Pertanian, 23-25 Mei di Bengkulu. http://library.unib.ac.id/koleksi/Donly\%20Avrin \%20-FP-Agr-2009.Txt.

Wattimena, G.A. 1988. Zat Pengatur Tumbuh Tanaman. Pusat Antar Universitas IPB Bogor Bekerja Sama dengan Lembaga Sumberdaya Informasi IPB, Bogor. 